\title{
ホタルルシフェラーゼ発光法を利用した 黄色ブドウ球菌迅速検出キットの評価
}

\author{
中西陽子*1 ・桜井直美 ${ }^{* 1}$ 熊田 董*2 $・$ 小池和 ${ }^{* 1}$ \\ (*1茨城県立医療大学医科学センター, ${ }^{2}$ つくば国際短期大学) \\ （受付 平成 11 年 5 月 19 日） \\ （受理 平成 11 年 9 月 22 日）
}

\section{An Evaluation of a Kit Applied Bioluminescence Method for the Detection of Staphylococcus aureus}

\author{
Yoko Nakanishi ${ }^{* 1}$, Naomi Sakurai ${ }^{* 1}$, Kaoru Kumada ${ }^{* 2}$ \\ and Kazuko A. KoIKE*1 \\ ${ }^{*}$ Ibaraki Prefectural University Center for Medical Sciences, \\ 4669-2 Ami, Ami-machi, Inashiki-gun, Ibaraki 300-0394) \\ ${ }^{* 2}$ Tsukuba International Junior College, 6-7-10 Manabe, \\ Tsuchiura-shi, Ibaraki 300-0051)
}

\begin{abstract}
A kit to detect Staphylococcus aureus, which often causes food poisoning and some other diseases, has been developed and commercially available. In the present study, the S. aureus rapid detection kit named "Check Lite BH" (Kikkoman Corporation) was evaluated and compared with the conventional method. This kit was designed based on the enzyme-linked immunosorbent assay (ELISA), in which the bioluminescence method is applied. If protein A of $S$. aureus is detected, it can be judged that the existence of $S$. aureus was verified. This method began to be sold as a kit product, so we evaluated the application of this kit in a food microbiological test.

(1) One hundred forty strains were examined. Ninety-five strains, which were identified to be $S$. aureus by traditional biochemical tests, were positive for bioluminescence activity by the kit. Thirty-five strains of Staphylococcus spp. except for S. aureus and 10 strains belonging to other genera of bacteria, which were identified by traditional tests, were all negative by this method, and cross reactions were not observed.

(2) By "direct method" (not enrichment), about $10^{4} \mathrm{cfu} / \mathrm{m} l$ of $S$. aureus FRI196E were detectable from cross-contamination samples with other bacteria in about 2 hours. Marked influences due to the contamination of other bacteria were not observed. Moreover there was a significant correlation between relative light units (RLU) and colony forming units (CFU) in the range of $10^{4}$ to $10^{6} \mathrm{cfu} / \mathrm{ml}$ of $S$. aureus.

(3) By the "enrichment method" (culture for 7 hours), $10^{1} \mathrm{cfu} / \mathrm{m} l$ of $S$. aureus FRI196E that was not detected on Egg-Yolk Mannitol Salt agar plate was detectable from the samples highly contaminated with $10^{5} \mathrm{cfu} / \mathrm{m} l$ of other mixed bacteria within a total of 9 hours.
\end{abstract}

Key words: Stapylococcus aureus, Bioluminescence, Protein A, Rapid detection kit

\section{緒言}

腸管出血性大腸菌食中毒の多発や，流通の国際化，食

*1 舀300-0394 茨城県稲敷郡阿見町阿見 4669-2

*2 巨300-0051 土浦市真鍋 6-7-10
品業界への HACCP 方式導入などに伴い, 食品衛生微生 物検查においては, より簡便かつ迅速で特異性が高く, 検出感度の優れた試験法の開発が求められている. 迅速 で高感度に微生物を検出する, あるいは菌数の推定を可 能とする方法の一つとして, バイオルミネッセンス法の 


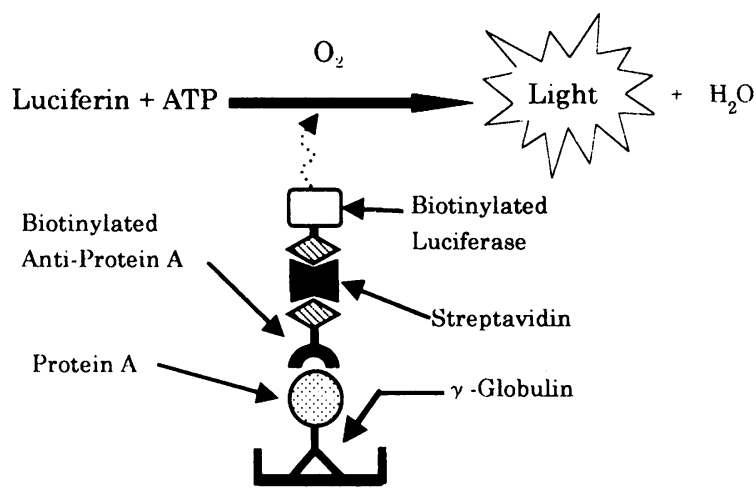

Fig. 1. The principle of the assay.

開発が進められている 1 5, 8, 9,11). バイオルミネッセンス 法は，ホタルルシフェラーゼが，ルシフェリンを基質と して，アデノシン三リン酸 (ATP) および酸素の存在下 で光子を発生する反応を利用したものである。したがっ て, 発光試薬としてルシフェリンールシフェラーゼを添 加することにより, 有酸素下で微生物中の ATP 量を, 発光量として測定することができる.

この原理を応用し，食中毒起因菌となり得る黄色ブド ウ球菌（Staphylococcus aureus 以下 S. aureus 之略す） を迅速かつ高感度に検出する目的で, S. aureus の約 90\% が産生するプロテインAを検出指標とした ELISA 法が開発された。この方法では，ビオチン標識抗 プロティン A 抗体を用い, 検出酵素にビオチン化ルシ フェラーゼとストレプトアビジンを $1: 1$ で結合させた 複合体を反応させる.さらに発光試薬としてルシフェリ ン, ATP 混合溶解液を添加することで，検体中に含まれ るプロティン A，すなわちS. aureus の有無を，発光量 測定値より判定するあのである (Fig. 1). 今回，このバ イオルミネッセンス法を利用したプロテイン A の検出 法が，S. aureus 検出用キット，ルシフェール BH（英名 Check Lite BH・キッコーマン(株)）として市販化され たため, 本キットの食品衛生微生物検査における有用性 を検討する目的で, ブドウ球菌食中毒由来株, methicillin 而性株 (MRSA), コアグラーゼ除性ブドウ球菌 (CNS)，並びに他菌属の細菌を用いて，従来法との比較 む含めて評価を行った。ささらに，清浄度の検查，モ二夕 リングを行おうとする食品衛生環境や食品などは, 通 常,「多種の微生物が混在している」而ことが予想される ため，他菌属の細菌が多量に混在する混合污染検体から のS. aureus 検出試験を行い, 検出の可否および検出限 界について検討を行った。

\section{材料および方法}

\section{1. 供試菌株}

試験に使用したS. aureus は，209P, FRI196E, FRIS6, FRI100, FRI184, FRI243, FRI361, FRI472 および食 中毒事例由来株 85 株, 茨城県立医療大学付属病院環境 より分離された MRSA 2 株の計 95 株であった. その他
の供試菌株は, 食品より分離されたコアグラーゼ陰性 Staphylococci(CNS) 11 菌種 35 株 (Table 1) と, Staphylococci 以外の細菌 10 菌種 10 株 (Table 2) であり, 合計 22 菌種 140 株であった。

\section{2. 従来法によるブドウ球菌検査}

従来法として, 卵黄添加マンニット食塩 (MSEY) 培地 (日水製薬(株)）での培養7,12)，ウサギプラズマ（栄研化 学(株)）を用いた遊離コアグラーゼ試験 ${ }^{1)}$, DNA 培地 (栄研化学(株)）によるDNase 試験 ${ }^{12)}$ を各々常法に従い 行った.

\section{3. キット操作手順}

ルシフェール BH に添付記載されている操作手順は以 下のとおりである。

1) 検体 $100 \mu l$ を $2 \mathrm{~m} l$ の増菌用培地*に接種し $37^{\circ} \mathrm{C}, 5$ 時間静置培養する.

2）培養液または検体希釈液を $100^{\circ} \mathrm{C}, 15$ 分間加熱殺 菌処理後, 室温まで放冷する.

3）固相を固定化したウェル*に，陰性対照*，陽性対 照*，殺菌済みの検体を各 $100 \mu l$ 分注後，ビオチン 標識抗プロテイン A 抗体*を $50 \mu l$ 添加し室温で 60 分間反応させる.

4) 洗浄液*でウェルを 4 回洗浄する.

5) ビオチン化ルシフェラーゼとストレプトアビジン $1: 1$ の複合体*を $100 \mu l$ 添加し, 室温で 15 分間反 応させる。

6) 洗浄液*でウェルを 4 回洗浄する.

7) 各ウェルを切り離し, 専用チューブにセットす る.このウェルに発光基質*を添加し, 発光検出器ル ミテスターK-210 (キッコーマン(株)) を用いて, 発光量を Relative Light Units (RLU) として測定 する.

8) 陰性対照の 1.5 倍以上の発光量が検出された場合 をS. aureus 陽性と判定する.

本キットでは， 5 時間の増菌培養時間が設定されてい るが，培養せずに ELISA により直接測定を行う場合を 「直接法」( 手順 2〜8) とした. なお, 「直接法」での操作 時間は約 2 時間であった。 また, 手順中, *を印した試薬 等はキットに付属のものを使用した.

\section{4. 本キットでの S. aureus の判定と交差反応性につ} いて

供試菌株計 22 菌種 140 株を，普通寒天培地（日水製 薬(株)) で $37^{\circ} \mathrm{C}, 24$ 時間培養後, 各コロニーをキット付 属の増菌用培地に接種し, 本キット手順に従い測定を 行った. Staphylococci 以外の細菌 10 株 (Table 2)につ いては，本キットで指定されている 5 時間増菌培養に加 えて, 24 時間増菌培養後の検体についても, キットによ る測定を行った．増菌後の各検体については，標準寒天 
培地（日水製薬(株)）を用いて，常法により菌数を測定 した。

\section{S. aureus の菌数と発光量の関係}

S. aureus FRI196E, 同 FRI361, 同 FRI472（いずれも エンテロトキシン産生株）の 3 株を, 各々普通ブイヨン (日水製薬(株)）で $37^{\circ} \mathrm{C}$, 一夜振とう培養後, 滅菌生理 食塩水で 10 倍段階希釈を行った。この各希棌菌液を検 体とし, 本キットを用いて「直接法」で測定を行った. 菌数算定は, 標準寒天培地を用い常法により行った.

\section{6. 検体中に混在する他種の細菌が及ぼす影響につい} $\tau$

S. aureus FRI196E を普通寒天培地で $37^{\circ} \mathrm{C}, 24$ 時間 培養したコロニーを, 滅菌生理食塩水に $\mathrm{OD}_{550}=1.5$ に なるよう懸濁した.これについて 10 倍段階希釈を行い, $10^{2} \sim 10^{7} \mathrm{cfu} / \mathrm{ml}$ のS. aureus FRI196E 希釈菌液を調製 した。検体中に混在させる他の細菌は, Table 2 の 10 菌 種の細菌を用いた。 各々の普通寒天培地 $37^{\circ} \mathrm{C}, 24$ 時間 培養コロニーを滅菌生理食塩水で $\mathrm{OD}_{550}=1.5$ となるよ う懸濁後, $10^{0}, 10^{4}, 10^{5}, 10^{6}, 10^{8} \mathrm{cfu} / \mathrm{ml}$ の各細菌希釈菌 液を調製し，各濃度ごとに 10 菌種混合菌液 $(9 \mathrm{ml})$ を調 製した. このそれぞれに，S. aureus FRI196E が $10^{1}$, $10^{2}, 10^{3}, 10^{4}, 10^{5}, 10^{6} \mathrm{cfu} / \mathrm{ml}$ の 6 通りずつ含まれるよ
うS. aureus FRI196E 希釈菌液を添加して検体とした. 混合前の各添加菌数は標準寒天培地にて確認を行った. 本キットの「直接法」で常に陽性と判定された S. aureus $\mathrm{FRI} 196 \mathrm{E}$ を $10^{4} \mathrm{cfu} / \mathrm{ml}$ 以上含む検体については「直接 法」で測定を行った. S. aureus FRI196E が $10^{4} \mathrm{cfu} / \mathrm{ml}$ 未満の検体については， キット手順で指定されている 5 時間増菌培養のほか, さらに 2 時間延長した 7 時間増菌 培養後の両方で測定を行った。増菌培養後の各検体は, マンニット食塩培地にて S. aureus の菌数を測定した.

\section{結果}

\section{1. 本キットによるS. aureus 判定結果と従来法との 比較}

本キットにより供試菌株の判定を行った結果は, Table 1 に示したとおり S. aureus 計 95 株すべてが $S$. aureus 陽性と判定されたが，CNS 計 35 株はすべて陰 性と判定された。従来法による試験結果では, S. aureus 95 株中 2 株 $(2.1 \%)$ が MSEY 寒天上で卵黄反応陰性を 示した以外は, コアグラーゼ試験, DNase 試験結果とも すべて陽性で S. aureus の性状に一致した。 また，CNS 35 株ではいずれの試験結果もすべて陰性であり, $S$. aureus に該当しなかった。これらのことから，本キット でのS. aureus の判定結果は従来法での結果と一致する ことが確認された。

Table 1. Number of the positive strains judged by current and traditional methods to detect and identify $S$. aureus and related strains

\begin{tabular}{|c|c|c|c|c|c|c|}
\hline \multirow{2}{*}{\multicolumn{2}{|c|}{ Bacteria }} & \multirow{2}{*}{$\begin{array}{l}\text { Number of } \\
\text { strain }\end{array}$} & \multicolumn{4}{|c|}{ Method } \\
\hline & & & Check Lite BH & $\begin{array}{l}\text { Egg yolk reaction } \\
\text { on MSEY agar }\end{array}$ & $\begin{array}{c}\text { Coagulase } \\
\text { test }\end{array}$ & DNase test \\
\hline \multirow[t]{8}{*}{ S. aureus } & $209 \mathrm{P}$ & 1 & 1 & 1 & 1 & 1 \\
\hline & FRI196E & 1 & 1 & 1 & 1 & 1 \\
\hline & FRIS-6 & 1 & 1 & 1 & 1 & 1 \\
\hline & FRI100 & 1 & 1 & 1 & 1 & 1 \\
\hline & FRI184 & 1 & 1 & 1 & 1 & 1 \\
\hline & FRI243 & 1 & 1 & 1 & 1 & 1 \\
\hline & FRI361 & 1 & 1 & 1 & 1 & 1 \\
\hline & FRI472 & 1 & 1 & 1 & 1 & 1 \\
\hline \multirow{3}{*}{\multicolumn{2}{|c|}{$\begin{array}{l}\text { S. aureus from food poisonings } \\
\text { S. aureus (methicillin resistant strains) } \\
\text { Total }\end{array}$}} & 85 & 85 & 83 & 85 & 85 \\
\hline & & 2 & 2 & 2 & 2 & 2 \\
\hline & & 95 & 95 & 93 & 95 & 95 \\
\hline \multicolumn{7}{|c|}{ Coagulase negative Staphylococcus spp. } \\
\hline \multicolumn{2}{|c|}{ S. auricularis } & 10 & 0 & 0 & 0 & 0 \\
\hline \multicolumn{2}{|c|}{ S. xylosus } & 7 & 0 & 0 & 0 & 0 \\
\hline \multicolumn{2}{|c|}{ S. epidermidis } & 4 & 0 & 0 & 0 & 0 \\
\hline \multicolumn{2}{|c|}{ S. simulans } & 3 & 0 & 0 & 0 & 0 \\
\hline \multicolumn{2}{|c|}{ S. caprae } & 3 & 0 & 0 & 0 & 0 \\
\hline \multicolumn{2}{|c|}{ S. capitis } & 2 & 0 & 0 & 0 & 0 \\
\hline \multicolumn{2}{|c|}{ S. haemolyticus } & 1 & 0 & 0 & 0 & 0 \\
\hline \multicolumn{2}{|c|}{ S. hominis } & 1 & 0 & 0 & 0 & 0 \\
\hline \multicolumn{2}{|c|}{ S. saprophyticus } & 1 & 0 & 0 & 0 & 0 \\
\hline \multicolumn{2}{|c|}{ S. saccharolyticus } & 1 & 0 & 0 & 0 & 0 \\
\hline \multicolumn{2}{|c|}{ S. warneri } & 1 & 0 & 0 & 0 & 0 \\
\hline \multicolumn{2}{|c|}{ S. sciuri } & 1 & 0 & 0 & 0 & 0 \\
\hline \multicolumn{2}{|l|}{ Total } & 35 & 0 & 0 & 0 & 0 \\
\hline
\end{tabular}


また，供試の Staphylococci 以外の細菌 10 株につい ては，本キットの指定培養時間である 5 時間培養後の検 体においても，また 24 時間培養後の $6.4 \times 10^{9} \sim 1.0 \times$ $10^{11} \mathrm{cfu} / \mathrm{m} l$ と顕著に菌数が増加した検体においても， 発光量はいずれもカットオフ值を下回り，陽性反応は認 められなかった (Table 2).

\section{S. aureus の菌数亡発光量の関係}

供試の S. aureus 3 株について, 本キットを用いて「直 接法」で測定を行った結果は，株により若干の発光量の 差異が認められたが, $10^{3} \sim 10^{4} \mathrm{cfu} / \mathrm{ml}$ 以上のとき，発 光量がいずれもカットオフ值以上となり，3株とも陽性 と判定された。 また， $10^{4} \mathrm{cfu} / \mathrm{ml}$ から $10^{6} \mathrm{cfu} / \mathrm{ml}$ の間 ではS. aureus 菌数と発光量に相関がみられた。しかし， $10^{6} \mathrm{cfu} / \mathrm{ml}$ 以上の菌数では, 菌数が増加しても発光量 は増加せず, $10^{10} \mathrm{cfu} / \mathrm{m} l$ 以上では逆に発光量の低下が 観察された (Fig. 2).

\section{3. 検体中に混在する他種の細菌が測定に及ぼす影響} について

清浄度のモニタリングを行おうとする環境あるいは食 品は, 通常, 多様な細菌に污染されていると考えられる. そこで，S. aureus 以外の菌種の細菌が混在する検体を 調製して測定を行い，本キットの検出感度と特異性につ いて検討を行った.

$10^{4} \sim 10^{6} \mathrm{cfu} / \mathrm{ml}$ の S. aureus FRI196E を含む各検体 を本キットの「直接法」で測定したところ，検体中に供 試の混合菌数が $10^{8} \mathrm{cfu} / \mathrm{ml}$ 混在した場合む比較的安定 した測定值が得られ，いずれの検体もS. aureus 陽性と 判定された. また, S. aureus FRI196E 単独の場合 (Fig. 2) と同様に S. aureus FRI196E 菌数と発光量に相関が 見られた (Table 3).

次に，さらに少量の S. aureus の検出を試みるべく, $10^{4} \mathrm{cfu} / \mathrm{ml}$ 末満の $S$. aureus FRI196E を含む検体につ いて増菌培養を行い，本キットで測定を行った結果と培

Table 2. The judgement about other genera of bacteria from bioluminescence values using by the kit after $5 \mathrm{hrs}$ enrichment and 24 hrs enrichment

\begin{tabular}{|c|c|c|c|c|c|}
\hline \multirow{2}{*}{ Bacteria } & \multirow{2}{*}{$\begin{array}{l}\text { Number of } \\
\text { strain }\end{array}$} & \multicolumn{2}{|c|}{ After 5 hrs enrichment } & \multicolumn{2}{|c|}{ After 24 hrs enrichment } \\
\hline & & RLU (judgement) & $\mathrm{cfu} / \mathrm{ml}$ & RLU (judgement) & $\mathrm{cfu} / \mathrm{ml}$ \\
\hline Streptococcus pyogenes & 1 & $136(-)$ & $7.2 \times 10^{7}$ & $188(-)$ & $6.4 \times 10^{9}$ \\
\hline Bacillus cereus & 1 & $123(-)$ & $1.7 \times 10^{8}$ & $173(-)$ & $2.8 \times 10^{10}$ \\
\hline Bacillus subtilis & 1 & $180(-)$ & $1.7 \times 10^{8}$ & $166(-)$ & $3.5 \times 10^{10}$ \\
\hline Acinetobacter calcoaceticus & 1 & $83(-)$ & $1.1 \times 10^{8}$ & $96(-)$ & $2.5 \times 10^{10}$ \\
\hline Escherichia coli & 1 & $200(-)$ & $3.7 \times 10^{8}$ & $96(-)$ & $4.0 \times 10^{10}$ \\
\hline Morganella morganii & 1 & $78(-)$ & $2.4 \times 10^{8}$ & $97(-)$ & $1.6 \times 10^{10}$ \\
\hline Pseudomonas aeruginosa & 1 & $87(-)$ & $1.8 \times 10^{8}$ & $103(-)$ & $1.0 \times 10^{11}$ \\
\hline Salmonella Typhimurium & 1 & $117(-)$ & $1.5 \times 10^{8}$ & $93(-)$ & $3.0 \times 10^{10}$ \\
\hline Serratia marcescens & 1 & $82(-)$ & $1.4 \times 10^{8}$ & $111(-)$ & $2.7 \times 10^{10}$ \\
\hline Vibrio parahaemolyticus & 1 & $121(-)$ & $4.8 \times 10^{8}$ & $98(-)$ & $1.0 \times 10^{11}$ \\
\hline
\end{tabular}

RLU: Relative light units (-): Negative of $S$. aureus

The cut off bioluminescence value was $285 \mathrm{RLU}$.

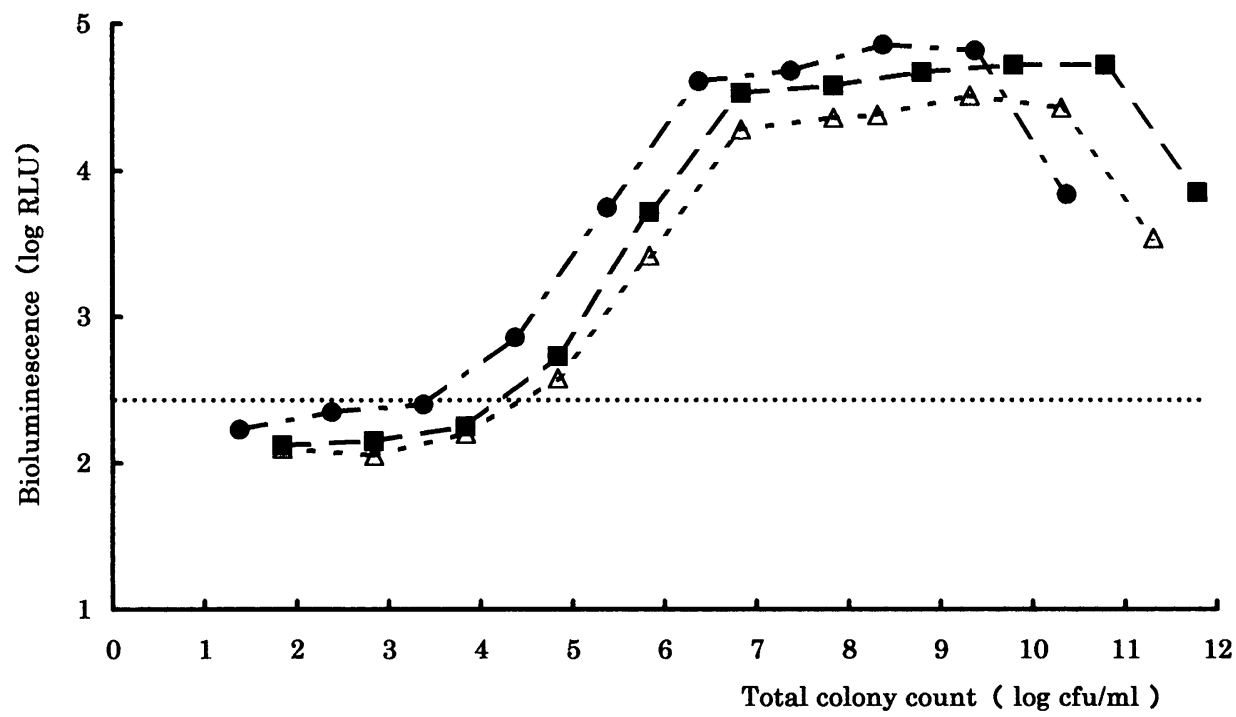

Fig. 2. Relationship between bioluminescence value and total colony count

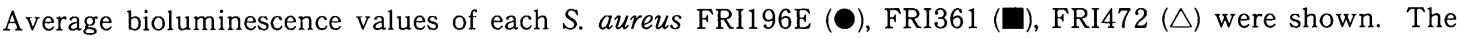
straight dotted line showed the cut-off bioluminescence value that was $1.5 \times$ the bioluminescence value of the negative control. Upper were positive of $S$. aureus and lower were negative of $S$. aureus. 
養後の S. aureus FRI196E 菌数測定值を Table 4 に示 した. 本キット指定の 5 時間培養を行った結果では, $S$. aureus FRI196E の増殖が混合菌の多寡によって大きく 影響され, 発光量からの判定結果が安定しなかったの で，培養時間を 7 時間に延長して検討を行った。 その結 果, 検体中の「混合菌数：S. aureus FRI196E 菌数」が

Table 3. Detection of $S$. aureus FRI196E using the kit from cross-contamination samples by "direct method"

\begin{tabular}{|c|c|c|c|}
\hline \multicolumn{2}{|c|}{ Sample $(100 \mu l)$} & \multirow[b]{2}{*}{$\begin{array}{c}\mathrm{RLU} \\
(\text { mean } \pm \mathrm{SD})\end{array}$} & \multirow[b]{2}{*}{$\begin{array}{l}\text { Judgement } \\
\text { of } \\
\text { S. aureus }\end{array}$} \\
\hline $\begin{array}{l}\text { Number of } \\
\text { S. aureus } \\
\text { FRI196E } \\
(\mathrm{cfu} / \mathrm{m} l)\end{array}$ & $\begin{array}{l}\text { Total number } \\
\text { of other } \\
\text { bacteria* } \\
(\mathrm{cfu} / \mathrm{ml})\end{array}$ & & \\
\hline \multirow[t]{4}{*}{$10^{4}$} & $10^{\circ}$ & $229 \pm \quad 13.5$ & + \\
\hline & $10^{4}$ & $265 \pm \quad 56.6$ & + \\
\hline & $10^{6}$ & $222 \pm \quad 20.5$ & + \\
\hline & $10^{8}$ & $244 \pm \quad 32.0$ & + \\
\hline \multirow[t]{4}{*}{$10^{5}$} & $10^{\circ}$ & $350 \pm \quad 50.6$ & + \\
\hline & $10^{4}$ & $485 \pm \quad 77.3$ & + \\
\hline & $10^{6}$ & $607 \pm 167.4$ & + \\
\hline & $10^{8}$ & $891 \pm 250.6$ & + \\
\hline \multirow[t]{4}{*}{$10^{6}$} & $10^{\circ}$ & $7323 \pm 1958.0$ & + \\
\hline & $10^{4}$ & $8040 \pm 2045.8$ & + \\
\hline & $10^{6}$ & $7368 \pm 2858.0$ & + \\
\hline & $10^{8}$ & $7169 \pm 1074.9$ & + \\
\hline
\end{tabular}

*: Ten other bacteria (Table 2) were mixed. RLU: Relative light units.

The cut-off bioluminescence value was 136RLU. +: Positive $\left\lceil 10^{5} \mathrm{cfu} / \mathrm{m} l\right.$ 以下： $10^{1} \mathrm{cfu} / \mathrm{m} l$ 以上」であれば， $S$. aureus 陽性と判定可能であった。一方，増菌検体を従来 のマンニット食塩培地で培養した結果は，検体中の「混 合菌数: S. aureus FRI196E 菌数」が $\left\lceil 10^{\circ} \mathrm{cfu} / \mathrm{ml}\right.$ 以下： $10^{1} \mathrm{cfu} / \mathrm{ml}$ 以上」，または $\Gamma 10^{4} \mathrm{cfu} / \mathrm{m} l$ 以下： $10^{2} \mathrm{cfu} /$ $\mathrm{m} l$ 以上」のときに, S. aureus コロニーが検出された. このことより, 混合菌が多量に混在する場合は本キット が比較的高感度であることが示された。

\section{考察}

代表的な食中毒起因菌の一つである $S$. aureus を，よ り迅速で簡便に検出するため，特異蛋白であるプロティ ン A の検出を指標とした測定法が報告されている ${ }^{10)}$. 長 原ら ${ }^{10)}$ は, ペルオキシダーゼ標識抗プロテイン A 鶏卵 抗体を用いた ELISA で吸光度測定による検出を行な い, 3〜6 時間の测定で $10^{5} \sim 10^{6} \mathrm{cfu} / \mathrm{ml}$ の S. aureus を 検出することが可能であると報告した。 さらに迅速性と 感度の向上をはかるべく，ビオチン標識抗プロテイン A 抗体，およびビオチン化ルシフェラーゼを用いて，バイ オルミネッセンス法を利用したELISAによる検出法が 開発された.このバイオルミネッセンス法では発光反応 が瞬時に生じることから, 本キットでは最短 5 時間の増 菌培養と約 2 時間の測定時間を併せて合計約 7 時間で $10^{1} \sim 10^{2} \mathrm{cfu} / \mathrm{ml}$ の S. aureus が検出可能であるとされ ている.

今回, 本キットを用いて従来法との比較を含めて評価 を行った結果は，本キットでは従来法で不可欠とされて いる平板培地での菌の分離が不要で，検体を直接測定で

Table 4. Detection of S. aureus FRI196E using the kit from cross-contamination samples after 5 hrs enrichment and 7 hrs enrichment

\begin{tabular}{|c|c|c|c|c|c|}
\hline \multicolumn{2}{|c|}{ Sample $(100 \mu l)$} & \multicolumn{2}{|c|}{ After $5 \mathrm{hrs}$ enrichment } & \multicolumn{2}{|c|}{ After $7 \mathrm{hrs}$ enrichment } \\
\hline $\begin{array}{l}\text { Number of } \\
\text { S. aureus FRI196E } \\
(\mathrm{cfu} / \mathrm{ml})\end{array}$ & $\begin{array}{l}\text { Total number of } \\
\text { other bacteria* } \\
\quad(\mathrm{cfu} / \mathrm{ml})\end{array}$ & $\begin{array}{c}\text { RLU } \\
\text { (mean } \pm S D)\end{array}$ & $\begin{array}{l}\text { Number of } \\
\text { S. aureus } \\
(\mathrm{cfu} / \mathrm{m} l)\end{array}$ & $\begin{array}{c}\text { RLU } \\
(\text { mean } \pm S D)\end{array}$ & $\begin{array}{c}\text { Number of } \\
\text { S. aureus } \\
(\mathrm{cfu} / \mathrm{m} l)\end{array}$ \\
\hline \multirow[t]{4}{*}{$10^{3}$} & $10^{0}$ & $309 \pm 86.6$ & $6.8 \times 10^{3}$ & $892 \pm 56.1$ & $1.4 \times 10^{4}$ \\
\hline & $10^{4}$ & $326 \pm 96.0$ & $3.7 \times 10^{3}$ & $694 \pm 68.1$ & $1.0 \times 10^{4}$ \\
\hline & $10^{5}$ & $268 \pm 113.5$ & $2.0 \times 10^{3}$ & $414 \pm 39.1$ & $4.2 \times 10^{3}$ \\
\hline & $10^{6}$ & $172 \pm 111.5(-)$ & ND & $277 \pm 8.5$ & $2.1 \times 10^{3}$ \\
\hline \multirow[t]{5}{*}{$10^{2}$} & $10^{0}$ & $231 \pm 32.0$ & $1.6 \times 10^{2}$ & $352 \pm 9.6$ & $2.3 \times 10^{3}$ \\
\hline & $10^{4}$ & $228 \pm 64.8$ & ND & $269 \pm 9.6$ & $1.2 \times 10^{3}$ \\
\hline & $10^{5}$ & $145 \pm 98.8(-)$ & ND & $230 \pm 20.2$ & ND \\
\hline & $10^{6}$ & $153 \pm 66.2(-)$ & ND & $209 \pm 1.6(-)$ & ND \\
\hline & $10^{8}$ & $160 \pm 81.7(-)$ & ND & $236 \pm 12.1$ & ND \\
\hline \multirow[t]{5}{*}{$10^{1}$} & $10^{\circ}$ & $228 \pm 51.6$ & ND & $262 \pm 17.2$ & $2.0 \times 10^{3}$ \\
\hline & $10^{4}$ & $159 \pm 70.9(-)$ & ND & $231 \pm 11.1$ & ND \\
\hline & $10^{5}$ & $146 \pm 75.4(-)$ & ND & $228 \pm 17.0$ & ND \\
\hline & $10^{6}$ & $98 \pm 50.9(-)$ & ND & $176 \pm 6.6(-)$ & ND \\
\hline & $10^{8}$ & $121 \pm 43.7(-)$ & ND & $225 \pm 38.2(-)$ & ND \\
\hline
\end{tabular}

*: Ten other genus bacteria (Table 2) were mixed. RLU: Relative light units ND: Not detected

The cut-off bioluminescence value was 228RLU. ND: Not detected. (-): These mean bioluminescence values were lower than the cut-off value, and these samples were judged negative of $S$. aureus. The counts of $S$. aureus were detected on Egg-Yolk Mannitol Salt agar plate. 
きるため，供試菌株中 3 株においても若干の差異は見ら れたが, $10^{3} \sim 10^{4} \mathrm{cfu} / \mathrm{ml}$ のS. aureus が含有されてい れば, 約 2 時間の操作時間で発光量測定值から $S$. aureus の存在の有無が判定可能であった。 また, $10^{4}$ $\mathrm{cfu} / \mathrm{m} l$ 以上の $S$. aureus FRI196E が含まれる検体で は, 同一検体中に, 供試した Streptococcus pyogenes, Bacillus cereus, Bacillus subtilis, Acinetobacter, Escherichia coli, Morganella morganii, Pseudomonas aeruginosa, Salmonella Typhimurium, Serratia marcescens, Vibrio parahaemolyticus などの細菌が多量に混在 しても，測定值に顕著な影響は見られず，約 2 時間で $S$. aureus FRI 196E を検出することが可能であり，特異性 が示された。

次に，このような多様な細菌が混在する検体から，さ らに少量の S. aureus の検出を試みるべく，検体の増菌 培養を行い本キットによる測定を行った。 プロテイン $\mathrm{A}$ の生産量はS. aureus の株によって差異があるため，本 キットでは検出可能な菌数を得るために, 最低であ 5 時 間の増菌培養時間が設定されている。今回, Staphylococci 以外の 10 菌種混合菌液に, S. aureus FRI196E を 加えた検体を測定した結果では，検体中にS. aureus 以 外の混合菌がわずかしか存在しない場合は，5時間の増 菌培養を行うことにより, $10^{1} \mathrm{cfu} / \mathrm{m} l$ すなわち, 検体試 料 $100 \mu l$ 中数個の S. aureus FRI196E を検出すること が可能であった，しかしながら，検体中の混合菌数が増 加するに従い，発光量が顕著に低下して S. aureus 検出 が困難となったため，増菌時間を延長する必要があっ た. 増菌培養後の菌液での測定值の低下は，培地成分に よる ELISA の反応阻害などが考えられるとの報告 ${ }^{10)}$ も ある，今回，増菌検体をマンニット食塩培地で培養した 結果では，検体中の混合菌数の増加に伴って，培地上の S. aureus のコロニー数が隇少する傾向が見られ，10 $\mathrm{cfu} / \mathrm{ml}$ 以上の混合菌が混在する検体では，S. aureus の コロニーは，検出困難であった．このことより，検体中 に混在する混合菌数に応じて S. aureus FRI196E の增 殖が抑制され，測定可能な菌数に達しなかったと推察さ れた。しかしながら，現行のキットを用いた試験では， 7 時間の増菌培養を行えば，測定時間の 2 時間を含めて 合計約 9 時間で, S. aureus 以外の細菌数が $10^{5} \mathrm{cfu} / \mathrm{ml}$ 混在する検体中からも，従来のマンニット食塩培地では 検出不可能であった $10^{1} \mathrm{cfu} / \mathrm{ml}$ の S. aureus FRI196E を検出できた．この検出限界菌数は，プロテイン A 生産 量の差異からS. aureus の株によって若干異なると考え られ，測定可能な菌数を得るため，さらに培養時間の延 長を要する場合ああろう。また，増菌培養方法について む今後, 選択性や増菌性などの培地成分, 培地容量, 接 種量などの条件について改良の余地があると思われる。

以上より, S. aureus 検出用キット・ルシフェール BH は, 多数の細菌に污染されている食品や衛生環境の検体 加ち迅速で感度良く, 特異的に供試の $S$. aureus を検
出できることが確認された，ただし，実際の食品中に存 在する菌は，必ずしも生菌とは限らない。したがって， 今後本キットを食品検査や環境検查へ適用する場合に は, 死菌検出の問題, あるいは, 加熱, 冷涷, 乾燥など による損傷菌についても考慮する必要があると考えられ る.

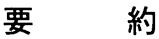

S. aureus の迅速検出法として，バイオルミネッセン ス法を応用した ELISA により，S. aureus 特有のプロテ イン A を検出する方法が開発され，迅速検出キットと して市販されたので本キットの有用性について評価を 行った.

1）本キットにより，供試の S. aureus 95 株はすべて S. aureus 陽性，CNS 35 株はすべて陰性と判定さ れ, 従来法での結果と一致した. Staphylococci 以外 の細菌 10 株む，菌数にかかわらず，いずれす陰性 之判定された。

2）供試の S. aureus 菌液を，本キットで測定した結 果は, 約 2 時間で $10^{3} \sim 10^{4} \mathrm{cfu} / \mathrm{ml}$ のS. aureus が 検出可能であった. また, $10^{4} \mathrm{cfu} / \mathrm{ml}$ から $10^{6} \mathrm{cfu} /$ $\mathrm{m} l$ の間で, S. aureus 菌数之発光量に相関関係が あった。

3）食品や環境サンプルなどを想定した混合菌検体の 試験結果は，増菌を行わない「直接法」では， $10^{4}$ $\mathrm{cfu} / \mathrm{ml}$ 以上の $S$. aureus FRI196E が含まれる場合 は, 混在する混合菌による顕著な影響は見られず, 約 2 時間で判定可能であり, $10^{4} \mathrm{cfu} / \mathrm{ml}$ から $10^{6}$ $\mathrm{cfu} / \mathrm{m} l$ の間では $S$. aureus FRI196E 菌数之発光量 に相関関係が見られた。一方，増菌培養を行った場 合は, 検体中の混合菌数の増加にとあないS. aureus FRI196E の増殖が抑制される傾向が認めら れたが， 7 時間の増菌培養を行えば，測定時間と併 せて合計 9 時間で $10^{5} \mathrm{cfu} / \mathrm{ml}$ の混合菌が混在する 検体から，マンニット食塩培地では検出不可能な $10^{1} \mathrm{cfu} / \mathrm{ml}$ のS. aureus FRI196E を検出すること が可能であった，今後, 増菌時の培地成分や培養方 法などに改良を加えることで，さらに迅速性や感度 の向上が期待される.

以上より本キットは，通常多数の細菌に污染されてい ると考えられる食品や環境などの検体からあ, 迅速で感 度良くS. aureus を検出できる可能性が示された。

本報の要旨は, 第 19 回日本食品微生物学会学術総会 （平成 10 年 10 月，神戸）において報告した.

謝辞

本研究を行うに当たり，貴重な情報および資料を提供 頂きました，キッコーマン株式会社 辰巳宏樹氏，中島 基雄氏, 福田 賢氏, 亚びに株式会社盛進 斉藤 渉氏 
に深く御礼申し上げます。

\section{文献}

1) Graumlich, T. R.: Estimation of microbial populations in orange juice by bioluminescence. J. Food Sci., 50, 116-117 (1985).

2) Griffith, J., Blucher, A., Fleri, J. and Fielding, L.: An evaluation of luminometry as a technique in food microbiology and a comparison of six commercially available luminometers. Food Sci. and Technol. Today, 8, 209-216 (1994).

3) Hattori, N. and Nakajima, M.: Rapid judgement of microbiological cleanliness in clean rooms by ATPbioluminescent method. International Confederation of Contamination Control Societies, Proceedings, 500-505 (1996).

4）金子 勉，横山弘美，高橋 強：ATP 測定による生乳・ ヨーグルト中微生物の迅速検出法. 食衛誌, 25, 193-197 (1997).

5) Kennedy, J.E. and Oblinger, J. L.: Application of bioluminescence to rapid determination of microbial levels in ground beef. J. Food Protect., 48, 334-340
(1985).

6）倉田 浩, 坂井千三：食品衛生之微生物. 食品の衛生微 生物検査, p. 1-62, 講談社, 東京 (1989).

7) 倉田 浩, 坂井千三：病原細菌の検査法. 食品の衛生微 生物検查, p. 242-334, 講談社, 東京 (1989).

8) LaRocco, K. A., Galligan, P., Little, K. J. and Spurgash, A.: A rapid bioluminescent ATP method for determining yeast contamination in a carbonated beverage. Food Technol., 39, 49-52 (1985).

9) Little, K. J., Pikelis, S. and Spurgash, A.: Bioluminescent ATP assay for rapid estimation of microbial numbers in fresh meat. J. Food Protect., 49, 18-22 (1986).

10）長原 歩, 福田 賢, 菊地 護, 五十君靜信, 五十嵐英 夫：抗プロテイン A 鶏卵抗体を用いた黄色ブドウ球菌の 簡易検出法. 食衛誌，39, 318-323 (1998).

11）小高秀正, 福田佳子, 水落慎吾, 掘米一己：食品の変敗 に関わる微生物中の ATP 含量. 日食微誌, 13, 29-34 (1996).

12）寺山 武, 五十嵐英夫：ブドウ球菌. 微生物検查必携細 菌・真菌検查第 3 版. 厚生省監修, 133-142, 日本公衆衛 生協会, 東京 (1993). 